\title{
SIGHAT TAKLIK TALAK DITINJAU DARI HUKUM PERJANJIAN
}

\author{
Akhmad Shodikin, Ubaidillah, Muhamad Aip Syaripuddin, \\ Fakultas Syariah dan Ekonomi Islam \\ IAIN Syekh Nurjati Cirebon \\ Email:shodikin73@gmail.com,ubai72@gmail.com, aipsyaripuddin17@gmail.com
}

\begin{abstract}
Abstrak
Sighat taklik talak dikatakan sebagai sebuah perjanjian, yang diucapkan seorang suami setelah pelaksanaan Akad Nikah yang sudah tertera dalam Akta Nikah mengenai janji talak yang digantungkan kepada keadaan tertentu yang mungkin akan terjadi dikemudian hari. Karena dinilai tidak ada unsur keadilan yang seharusnya ada dalam sebuah perjanjian, dari sinilah penulis merasa perlu untuk mencoba menganalisis terkait kedudukan taklik talak ditinjau dari Hukum Perjanjian, demi keterwujudannya sebuah keluarga yang sakinah, mawaddah dan rahmah. Adapun hasil penelitian ini : kedudukan taklik talak jika ditinjau dari hukum Perjanjian Kitab Undang-undang Hukum Perdata, ditemukan tidak adanya kesesuaian ketentuan sebuah perjanjian dalam pasal 1313 yang menjelaskan sebuah perjanjian dilaksanakan oleh dua orang atau lebih, sedangkan taklik talak termasuk perjanjian sepihak, serta tidak sesuai dengan pasal 1320 mengenai persyaratan sebuah perjanjian terhadap poin 2 dan pasal 1329 mengenai kecakapan seseorang dalam membuat perjanjian, maka jika dilihat dari Kitab Undang-undang Hukum Perdata, Taklik talak bukan suatu perjanjian pada umumnya kemudian tidak ada dampak khusus bagi yang tidak melakukan taklik talak dalam hal ini tidak mengikat.
\end{abstract}

Kata Kunci : Taklik talak, Kedudukan, Kitab Undang-Undang Hukum Perdata, Implikasi.

\begin{abstract}
Abstrack
Sighat taklik talak is said to be an agreement, which a husband uttered after the execution of the Nikah Act which is already in the Deed of Marriage regarding the promise of divorce which is suspended to the circumstances which may occur in the future. Because it is considered that there is no element of justice that should exist in a treaty, from which the writer feels it is necessary to try to analyze the relationship of the not-talak position of the law of the Covenant, for the sake of a family of sakinah, mawaddah and rahmah. The result of this study: the position of talak talak if viewed from the Law of the Civil Code Law found there was no suitability of the provisions of an agreement in article 1313 which describes an agreement executed by two or more persons, while the talak taklik included a unilateral agreement, in accordance with article 1320 regarding the terms of an agreement to point 2 and article 1329 regarding a person's ability to enter into an agreement, if viewed from the Civil Code, Taklik talak is not an agreement in general then there is no special impact for those who do not perform talak talak in this case is not binding.
\end{abstract}

Keywords: Taklik talak, In a Taklik talak, Book of Law, Implicasi. 


\section{A. Pendahuluan}

Hubungan keluarga terjadi setelah perkawinan dan bertujuan untuk membentuk keluarga penuh dengan cinta, kasih sayang dan bahagia. Dalam keluarga terdapat hak dan kewajiban yang harus dilaksankan oleh keluarga tersebut, yaitu oleh pasangan suami istri demi terwujudnya keluarga yang harmonis.

Dalam Undang-Undang

Perkawinan Nomor 1 Tahun 1974 menjelaskan yang dimaksud Perkawinan adalah

"Ikatan lahir batin antara seorang pria dengan seorang wanita sebagai suami istri dengan tujuan membentuk keluarga (rumah tangga) yang bahagia dan kekal berdasarkan Ketuhanan yang Maha Esa". ${ }^{1}$

Landasan perkawinan telah Allah SWT atur dalam firman-Nya dalam Surat Ar-Rum ayat 21:

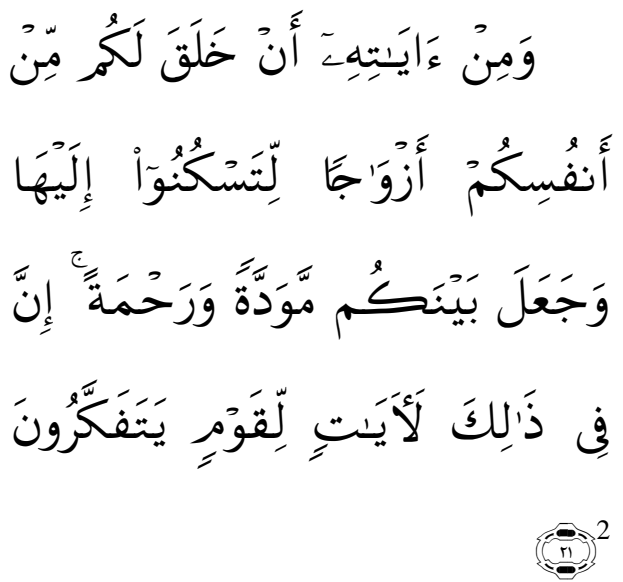

Artinya : "Dan di antara tandatanda kekuasaan-Nya ialah Dia menciptakan untukmu istri-istri dari jenismu sendiri, supaya kamu cenderung dan merasa tenteram kepadanya, dan dijadikan-Nya diantaramu rasa kasih dan sayang. Sesungguhnya pada yang demikian itu

1 Undang-Undang Perkawinan Bab I “ Dasar Perkawinan " pasal 1, (Bandung : Citra Umbara, 2012), 2.

${ }^{2}$ Kementrian Agama Republik Indonesia, Al-Qur'an Surat Ar-Rum 30:21, (Surabaya : Halim Publising dan Distributing, 2013), 406. benar-benar terdapat tanda-tanda bagi kaum yang berfikir."

Adanya hak dan kewajiban dalam keluarga bertujuan untuk membentuk rumah tangga yang penuh dengan ketenangan, kenyamanan, ketenteraman serta penuh dengan kasih sayang. Dengan kata lain, sebuah keluarga bertujuan untuk menciptakan hal-hal sebagai berikut :

1. Sakinah, artinya tenang.

2. Mawaddah, artinya keluarga yang di dalamnya terdapat rasa cinta, yang berkaitan dengan hal-hal yang bersifat jasmani.

3. Rahmah, artinya keluarga yang di dalamnya terdapat rasa kasih sayang yakni hal-hal yang bersifat kerohanian. $^{3}$

Dalam Kompilasi Hukum Islam, perceraian dapat terjadi karena adanya pelanggaran terhadap taklik talak, yang dimaksud taklik talak dalam perkawinan adalah perjanjian yang diucapkan suami setelah akad nikah yang dicantumkan dalam Akta Nikah berupa janji talak yang digantungkan kepada keadaan tertentu yang mungkin terjadi di masa yang akan datang. Sedangkan tujuan taklik talak yaitu semata memberikan ruang kepada suami supaya lebih berhati-hati dalam melaksanakan hak dan kewajiban dan berupaya memberikan hak dan kewajiban kepada istrinya. Dalam Kompilasi Hukum Islam pasal 114 tentang putusnya perkawinan, menjelaskan bahwa "putusnya perkawinan yang disebabkan karena perceraian dapat terjadi karena talak atau berdasarkan gugatan perceraian." Jadi dalam hal ini, istri memang tidak ada hak untuk melakukan talak, tetapi menurut Kompilasi Hukum Islam, istri boleh mengajukan gugatan perceraian terhadap suaminya.

${ }^{3}$ Lihat, Cyril Glasse, Enskilopedi Islam Ringkas. Terj. Ghufron Mas'udi (Jakarta : Raja Grafindo, 1999), 35. 
Dalam Kompilasi Hukum Islam tentang taklik talak, bahwa taklik talak adalah perjanjian talak yang ditangguhkan dalam keadaan tertentu. Akan tetapi dalam literatur fikih klasik tidak ditemukan bahasan khusus dengan nama perjanjian dalam perkawinan, yang ada dalam pembahasan fikih dan diteruskan dalam sebagian kitab fikih dengan maksud yang sama adalah "Persyaratan dalam Perkawinan". Kaitan antara syarat dalam perkawinan dengan perjanjian dalam perkawinan adalah karena perjanjian itu berisi syarat-syarat yang harus dipenuhi oleh pihak yang melakukan perjanjian dalam arti pihak-pihak yang berjanji untuk memenuhi syarat yang ditentukan. Namun perjanjian itu tidak sama dengan sumpah, karena sumpah dimulai dengan ucapan sumpah, yaitu wawllahi, billahi dan tallahi. Dan membawa akibat dosa bagi yang tidak memenuhinya. ${ }^{4}$

Sehingga hakikat pernikahan
adalah sebuah
overeenkomst, kontrak, akad. Sebuah perjanjian (overeenkomst) akan menimbulkan perikatan (verbintenis) yang akan membawa segala risiko dan akibatnya dikemudian hari.

Hal lain yang mendasar tentang perjanjian sebagaimana hukum agama Islam perkawinan itu sebagai suatu perjanjian (overeenkomst) dilakukan oleh wali dengan mengijabkan (menyerahkan) dan mempelai laki-laki mengkabul (menerimanya) sebagai istrinya. Maka disitulah perjanjian dalam perkawinan terjadi.

Berbicara mengenai perjanjian, dalam Kompilasi Hukum Islam menjelaskan pada pasal 45 yaitu kedua calon mempelai dapat mengadakan perjanjian perkawinan dalam bentuk :

1. Taklik talak, dan.

\footnotetext{
${ }^{4}$ Amir Syarifuddin, Hukum Perkawinan di Indonesia, 201.
}

2. Perjanjian lain yang tidak bertentangan dengan hukum Islam.

Dalam Pasal 46 disebutkan :

1. Isi taklik talak tidak boleh bertentangan dengan hukum Islam.

2. Apabila keadaan yang disyaratkan dalam taklik talak betul-betul terjadi kemudian, tidak dengan sendirinya talak jatuh. Supaya talak sungguhsungguh jatuh, istri harus mengajukan pesoalannya ke Pengadilan Agama.

3. Perjanjian taklik talak bukan suatu perjanjian yang wajib diadakan dalam setiap perkawinan, akan tetapi sekali taklik talak sudah diperjanjikan tidak dapat dicabut kembali. $^{5}$

Arti perjanjian atau kontrak secara tersendiri yaitu dalam Bahasa Arab disebut dengan akad, kata "akad" berasal dari bahsa Arab Al-aqdu yang berarti ikatan atau simpul tali. ${ }^{6}$ Kata "akad" secara terminologi fikih adalah "Perikatan antara ijab dengan kabul secara yang dibenarkan syara. ${ }^{7}$

Perjanjian sendiri mempunyai pengertian suatu peristiwa dimana seorang berjanji kepada orang lain atau dimana kedua orang tersebut saling berjanji untuk melaksanakan suatu hal. ${ }^{8}$. Karena taklik talak tidak ada keharusan untuk dibaca setelah akad nikah berlangsung, tetapi jika diucapkan maka akan mengikat layaknya suatu perjanjian, maka harus dilaksanakan, serta jika suami melanggar, lstri boleh mengajukan Gugat Cerai.

5 Kompilsi Hukum Islam, Bab VII pasal 45,46, (Bandung : Citra Umbara, 2012), 335.

${ }^{6}$ Abd Shomad, Hukum Islam, 172.

7 T.M. Hasbi Ash Shiddieqy, Pengantar Fiqih Muamalah, (Jakarta: Bulan Bintang, 1947), 21.

${ }^{8}$ Subekti, Hukum Perjanjian, ( Jakarta : Pembimbing masa, 2010), terjemah ke-III, 1. 


\section{B. Metode Penelitian}

Artikel ini menggunakan penelitian kualitatif yang bersifat kajian pustaka. Data-data dalam artikel ini berasal dari sumber yang bersifat pustaka. Sumbersumber tersebut berupa buku, artikel ilmiah, dan sumber pustaka lain yang mendukung permasalahan yang tengah dikaji yaitu tentang Sighat Taklik Talak, Hukum Perjanjian, dan hukum Islam. Data-data diperoleh dengan membaca, memahami, dan menganalisis bahan pustaka yang telah dikumpulkan. Data-data dalam artikel ini disajikan dengan cara naratifdeskriptif. Teknik analisis data yang digunakan adalah kondensasi data, penyajian data, dan penarikan kesimpulan.

\section{Pembahasan}

\section{Pengertian Sighat Taklik Talak}

Sighat Taklik Talak dalam perkawinan Islam bukanlah suatu hal yang tabu karena yang terjadi di masyarakat sudah menjadi kebiasaan yaitu setelah selesainya akad perkawinan petugas pencatat perkawinan (P3N) menyuruh kepada suami untuk membacakan Sighat taklik talak baik di muka umum maupun pembacaannya dilakukan di Rumah.

Secara sempit kata Sighat mengandung arti yaitu rupa, asal, macam, bangun. ${ }^{9}$ Sighat ini banyak dijumpai dalam hal perkwianan misalnya dalam hal ijab dan qabul seperti halnya Sighat ijab dan Sighat qabul. Secara etimologis bahwa kata taklik berasal dari kata Bahasa Arab yaitu allaqa yu'alliqu ta'liqan $^{10}$ yang mengandung arti menggantungkan, Sedangkan kata talak sendiri berasal dari kata thallaqa yuta'aliqu tat'liqan mengandung arti menceraikan, secara

9 Mahmud Yunus, Kamus Arab-Indonesia, (Jakarta : Hidayat Agung,1989), 224.

10 M. Mahmud Yunus, Kamus Arab Indonesia,(Jakarta:Yayasan Penyelenggara / Penafisiran Al-Qur'an), 13. jelas pembahasan talak dalam AlQur'an tidak terdapat ayat-ayat yang menyuruh atau melarang eksistensi percerain itu. ${ }^{11}$ Sehingga Sighat taklik talak dapat diartikan yaitu suatu perceraian yang digantungkan atau bisa diartikan sebagai perpisahan antara suami dan istri yang digantungkan terhadap sesuatu.

Pengertian lain tentang istilah Sighat taklik talak atau ucapan talak yang bergantung adalah apa yang dijadikan suami untuk mencapai talak digantungkan pada syarat suatu sifat. Seperti ucapan seorang suami kepada istri : "Jika engkau pergi ke teater maka engkau tertalak". ${ }^{2}$ Maka jika istri benar-benar pergi ke teater maka jatuhlah talak, akan tetapi jika istri tidak melakukan apa yang disyaratkan maka talak tidak terjadi.

Dalam pengertian lain mengenai Sighat taklik talak dijelaskan bahwa yang dimaksud dengan Sighat Taklik Talak yaitu

"Sebentuk perjanjian dalam perkawinan yang didalamnya disebutkan beberapa syarat yang harus dipenuhi oleh suami. Dan jika suami tidak memenuhinya, maka istri yang tidak rela dengan itu dapat mengajukannya ke Pengadilan Agama sebagai alasan untuk perceraian". 13

Dalam Kitab Fiqih as Sunnah Sayyid Sabiq menyebutkan bahwa talak ada dua macam yaitu al-Tanjiz dan althaliq. Tanjiz adalah talak yang dilakukan suami terhadap istrinya pada waktu seketika dan tidak digantungkan terhadap syarat sebab tertentu,

11 Amir Syarifuddin, Hukum Perawinan Islam Di Indonesia, 200.

${ }^{12}$ Abdul Aziz Muhamad Azam dan Abdul Wahab Sayyed Hawwas. Fiqih Munakahat Khitbah,Nikah danTalak, (Jakata : Sinar Grafika Offset 2009), 274.

13 Amir Syarifuddin, Hukum Perkwinan Islam di Indonesia, 226. 
sedangkan Thaliq adalah Talak yang dilakukan oleh suami terhadap istrinya akan tetapi digantungkan terhadap syarat atau sebab tertentu. ${ }^{14}$ digantungkan terhadap syarat atau sebab tertentu. ${ }^{15}$

Selaras dengan pengertian di atas Kompilasi Hukum Islam memberikan pengertian secara jelas tentang Sighat taklik talak yaitu

"Perjanjian yang diucapkan oleh calon mempelai pria setelah akad nikah yang dicantumkan dalam akta nikah berupa janji talak yang digantungakan kepada keadaan tertentu yang mungkin terjadi di masa yang akan datang". 16

Pandangan masyarakat pada umumnya terkait taklik talak merupakan perceraian yang terjadi antara suami dan istri yang digantungkan kepada sesuatu biasanya dilakukan setelah akad nikah berlangsung. Maka jika terjadi pelanggaran terhadap apa yang dibuat dan disepakati inilah yang menjadi dasar jatuhnya talak atau perceraian atau terjadinya perpisahan. ${ }^{17}$

Adapun syarat-syarat taklik yaitu (1) syarat yang digantungkan kepada talak tidak memiliki bahaya bagi keberadaanya, maksudnya memiliki kemungkinan terjadi dan tidak akan terjadi. Jika ada maka talaknya langung terlaksana. (2) adanya perkara yang djadikan taklik dan istri yang menjadi objek talak, yaitu si perempuan benar-

${ }^{14}$ Sayyid sabiq, Fiqih As Sunnah Jilid II, (Mesir: al-Fath al-I'lam al-'Arabi, 2000), 123

15 Sayyid sabiq, Fiqih As Sunnah Jilid II, (Mesir: al-Fath al-I'lam al-'Arabi, 2000), 123

16 Kompilasi Hukum Islam Buku I Pembahasan Hukum Perkawinan pada Bab I Ketetntaun Umum ayat 5, (Bandung : Citra Umbara, 2012), 323.

${ }^{17}$ Khairudin Nasution, kekeliruan Spiritual Perempuan Dalam Taklik Talak dan Perjanjian Perkawinan, 2008.

http://www.badilag.net/data/ARTIKEL/Kekuatan Spiritual Perempuan.pdf. Diakses pada tanggal 23 Maret 2018 benar berada dalam kondisi perkawinan. Hukum talak yang ditaklik atau sumpah untuk menjatuhkan talak, pada dasarnya para fuqaha saling berselisih pendapat mengenai sumpah untuk menjatuhkan talak atau talak yang ditaklik.

Dalam hal ini ulama fiqih berbeda pendapat yaitu (1) para imam keempat mazhab berpendapat, jatuh talak yang ditaklik ketika ada perkara yang dijadikan taklik, apakah perkara ini dilakukan oleh salah satu suami istri, atau suatu perkara yang terjadi karena kehendak Allah. Apakah talik ini berupa sumpah, yaitu dorongan untuk melakukan sesuatu atau meninggalkannya, atau untuk menegaskan suatu berita, ataupun sebagai suatu syarat yang dimaksudkan untuk mendapatkan balasan ketika syarat terwujud. (2) Mazhab Zhahiri dan Syi'ah Imamiyyah berpendapat, sumpah dengan talak atau talak yang ditaklik jika didapati perkara yang digantungkan tidak membuat talak jatuh dari asalnya. Meskipun taklik ini berbentuk sumpah, yaitu dimaksudkan sebagai dorongan untuk melakukan sesuatu atau meninggalkannya, atau untuk menegaskan suatu berita. Ataupun tidak berbentuk sumpah, yaitu yang dimaksud untuk menjatuhkan talak manakala terjadi apa yang dia jadikan sebagai taklik. (3) Ibnu Taimiyyah dan Ibnu Qayyim memberikan pendapat secara detail, jika taklik berbentuk sumpah atau dalam bentuk sumpah, dan didapati perkara yang dijadikan taklik, maka tidak terjadi talak. Menurut ibnu taimiyyah boleh kafarat sumpah jika dia langgar sumpahnya.

Dan menurut Ibnu Qayyim tidak ada kafarat bagi sumpah ini. Sedangkan jika taklik berupa syarat atau bukan 
dalam bentuk sumpah, jatuh talak ketuka terjadi syarat. ${ }^{18}$

\section{Ruang Lingkup Sighat Taklik Talak}

Sighat taklik talak yang dimaksud di Kompilasi Hukum Islam merupakan sebuah bentuk perkawinan dalam Islam yang di dalamnya disebutkan beberapa syarat yang harus dipenuhi oleh suami. Jika suami tidak memenuhinya, maka istri yang tidak rela dengan itu dapat mengajukannya ke pengadilan sebagai alasan untuk perceraian. ${ }^{19}$ Dengan adanya perjanjian yang dibuat oleh suami maka si istri punya kehendak untuk mengajukan gugatan perceraian atas dasar pelanggaran Sighat taklik talak yang dilakukan suami dan istri tersebut tidak ridha atas pelanggaran yang dilakukan suami.

Seorang istri yang akan mengajukan gugatan perceraian ke pengadilan harus ada cukup alasan untuk dijadikan bahan pertimbangan hakim dalam memutuskan perkara perceraian, hal ini sebagaimana telah diatur dalam pasal 39 Undang-Undang Perkawinan yang terdiri dari 3 ayat dengan rumusan sebagai berikut :

1. Perceraian hanya dapat dilakukan di depan sidang Pengadilan setelah pengadilan yang bersangkutan berusaha dan tidak berhasil mendamaikan kedua belah pihak

2. Untuk melakukan perceraian harus ada cukup alasan, bahwa antara suami dan istri itu tidak akan dapat hidup rukun sebagai suami istri
3. Tata cara perceraian di depan sidang pengadilan diatur dalam perUndang-Undangan tersendiri. ${ }^{20}$

Dari ayat 2 pada pasal 39 UndangUndang Perkawinan sudah memberikan pemahaman bahwa perceraian yang dilakukan harus adanya alasan yang cukup yang nantinya bisa diajukan ke pengadilan, salah satunya dengan adanya pelanggaran Sighat taklik talak yang dilakukan suami.

Sighat taklik talak yang berlaku dibeberapa tempat yaitu yang diucapkan suami setelah akad nikah dilakukan $^{21}$ akan memberikan dampak hukum, jika suami melalaikan kewajibannya dan istrinya berulang kali mengingatkannya namun tetap tidak adanya perubahan,maka al-Qur'an seperti yang terdapat dalam surat anNisa/4: 128 menganjurkan perdamaian di mana istri diminta untuk lebih sabar menghadapi suaminya dan hak-haknya dikurangi untuk sementara waktu, semuanya ini bertujuan agar perceraian tidak terjadi. $^{22}$

\section{Talak}

Dasar Hukum Sighat Taklik

Dalam Undang-Undang

Perkawinan tidak dijelaskan mengenai ketentuan Sighat taklik talak, hanya saja dalam Undang-Undang perkawinan dijelaskan bahwa pada pasal bab $\mathrm{V}$ pada pembahasan perjanjian perkawinan pada pasal 29 ayat 1 dijelaskan bahwa, pada waktu atau sebelum perkawinan dilangsungkan, kedua pihak atas persetujuan bersama dapat mengadakan perjanjian tertulis yang disahkan oleh Pegawai pencatat

${ }^{20}$ Undang-Undang R.I Nomor 1 tahun 1974 tentang Perkawinan dan Kompilasi Hukum Islam, (Bandung : Citra Umbara 2016) cet. Ke-7, 13

21 Amir Syarifuddin, Hukum Perkwinan Islam di Indonesia, 225.

22 Amiur Nuruddin dan Azhari Akmal Tarigan, Hukum Perdata Islam di Indonesia Studi Kritis Perkembangan Hukum Islam dan Fikih, UU No 1/1974 sampai KHI, ( Jakarta : Kencana Prenada Media Grup 2012) cet. Ke-4, 211. 
perkawinan, setelah mana isinya berlaku juga terhadap pihak ketiga sepanjang pihak ketiga tersangkut, ${ }^{23}$ dari sini Undang-Undang perkawinan tahun 1974 tidak secara jelas memberikan dasar hukum tentang Sighat taklik talak.

Akan tetapi pemahaman masyarakat menilai Sighat taklik talak ini merupakan hal yang lumrah dan sering terjadi setelah akad nikah berlangsung karena bertujuan untuk menjamin hak-hak wanita dari tindakan diskriminatif dari suami, hal ini sesuai dengan penejalasan dalam karya tulis yaitu menjelaskan bahwa taklik talak dimaksudkan untuk menjamin istri yang tepat dan untuk melindungi mereka dari tindakan diskriminatif dan kesewenangwenang dari suami. ${ }^{24}$

Dari sinilah seolah Sighat taklik talak harus selalu diadakan dalam sebuah perkawinan Islam, dasar hukum mengenai Sighat taklik talak dalam perkawinan Islam tidak dijelaskan akan tetapi dalam Kompilasi Hukum Islam dalam Bab VII dalam pembahasan Perjanjian Perkawinan pada pasal 45 ayat 1 menjelaskan bahwa

"Kedua calon mempelai dapat mengadakan perjanjian perkawinan dalam bentuk : 1 . Taklik talak dan 2. Perjanjian lain yang tidak bertentangan dengan hukum Islam". ${ }^{25}$

\section{Penjelasan lain dalam dasar pelaksanaan Sighat taklik talak sebagaimana yang dijelaskan dalam jurnal studi Islam bahwa Majelis Ulama Indonesia pada tanggal 23 Rabiul Akhir}

${ }^{23}$ Undang-Undang R.I Nomor 1 tahun 1974 tentang Perkawinan dan Kompilasi Hukum Islam, 10 .

${ }^{24}$ Mutohin, "Taklik talak dalam presfektif gender”. MUWAZAH, Volume. 4:2, (Desember 2012) : 21

${ }^{25}$ Undang-Undang R.I Nomor 1 tahun 1974 tentang Perkawinan dan Kompilasi Hukum Islam, 335.
$1417 \mathrm{H}$, bertepatan dengan 7 September 1996, menetapkan keputusan fatwa-nya menyatakan bahwa Mengucapkan Sighat taklik talak dalam perkawinan tidak diperlakukan lagi. Dengan alasan keputusan ini dapat digambarkan sebagai berikut : 1) Bahwa materi Sighat taklik talak pada dasarnya telah dipenuhi dan tercantum dalam Undang-Undang No. 1 tahun1974 tentang perkawinan dan UndangUndang No.7 tahun 1989 tentang Peradilan Agama; 2) Menurut Kompilasi Hukum Islam pasal 46 ayat 3 menjelaskan bahwa perjanjian taklik talak bukan merupakan keharusan dalam setiap perkawinan; dan 3) Bahwa konteks mengucapkan Sighat taklik talak menurut sejarahnya adalah untuk melindungi hak-hak wanita, di mana taklik talak waktu itu taklik talak belum ada dalam peraturan perUndangUndangan perkawinan. ${ }^{26}$

Pelaksanaan Sighat Taklik Talak

Ketentuan Sighat taklik talak dalam perjalanannya khususnya di Indonesia mempunyai nilai klasual yang biasa memberikan pemahaman yang berbeda dalam menafsirkan Sighat taklik talak yang bisa ditinjau dari beberapa asfek ilmu pengetahuan, hal ini masih menghasilkan polemik dikalangan akademisi karena Sighat taklik talak belum memiliki dasar hukum yang kuat, hanya saja dalam Kompilasi Hukum Islam menjelaskan bahwa Sighat taklik talak termasuk kedalam sebuah perjanjian perkawinan Islam seperti yang tercatat dalam pasal $45 .^{27}$ Dengan penjelasan seperti ini maka kedua belah pihak yang akan menikah dibolehkan mengadakan sebuah perjanjian yang dirasa perlu.

26 Hasanudin, "Kedudukan taklik talak dalam perkawinan ditnjau dari hukum Islam dan Hukum Positif'. Medina-Te, Jurnal Study Islam, Volume, 1 (Juni 2016) : 49.

${ }^{27}$ Undang-Undang R.I Nomor 1 tahun 1974 tentang Perkawinan dan Kompilasi Hukum Islam, 335. 
Masyarakat yang belum mengetahui ketentuan-ketentuan Sighat taklik talak akan menilai seolah-olah dalam sebuah perkawinan harus adanya pembacaan Sighat taklik talak setelah selesainya akad nikah berlangsung yang dipandu oleh penghulu atau pihak lain yang telah diberi tugas yang dibacakan oleh pihak suami dan istri menyetujuinya dengan berbekal pemahaman dengan membacakan Sighat taklik talak ini seoalah menjunjung tinggi dalam hal melindungi istri, serta ketika suatu saat suami melalaikan dalam melaksanakan hak dan kewajibannya terhadap istrinya dan istrinya tidak ridha maka bisa diajukan ke Pengadilan Agama sebagai alasan terjadinya perceraian.

Dengan adanya Sighat taklik ini sebagaimana yang dijelskan dalam jurnal study Islam menjelaskan bahwa Sighat taklik talak dirumuskan sedemikian rupa agar sang istri memperoleh perlakuan yang baik dari pihak suaminya, jika istri diperlakukan sewenang-wenang oleh suaminya dan dengan keadaan tertentu, istri tidak ridha, maka ia dapat mengajukan gugatan perceraian ke pengadialan agama dengan alasan suami telah melanggar taklik talak. Pembahasan tentang taklik talak ini sebagai alsan perceraian, telah dibicarakan oleh para fuqaha dalam berbagai kitab fiqih, dan ternyata mereka berbeda pendapat tentang hal itu. ${ }^{28}$

Senada dengan penjelasan di atas mengenai kekuatan Sighat taklik talak dalam hal dasar hukum masih lemah sehingga masih menimbulkan banyaknya pendapat sehingga para fuqoha saling berselisish mengenai pembahasan Sighat taklik talak ini.

Dalam keterangan lain adanya Sighat taklik talak supaya bisa

28 Hasanudin, "Kedudukan taklik talak dalam perkawinan ditnjau dari hukum Islam dan Hukum Positif'. Medina-Te, Jurnal Study Islam, Volume, 1 (Juni 2016) : 48. meminimalisir tindakan suami dapat terjadi adanya suatu kelalaian dari pihak suami untuk memenuhi kewajibannya pada istri, baik nafkah lahir maupun nafkah batin, berkenaan dengan tugas suami berangkat dari hadits Nabi Muhamad SAW, dinyatakan bahwa di antara kewajiban suami terhadap istrinya adalah pertama, memberi sandang dan pangan. kedua, tidak memukul wajah jika terjadi Nusyuz. Ketiga, tidak mengolok-olok dengan mengucapkan hal-hal yang dibencinya. Keempat, tidak menjauhi istri atau menghindari istri kecuali di dalam rumah. ${ }^{29}$

\section{Pengertian Perjanjian dalam Hukum Perdata}

Hubungan antara manusia satu dengan yang lainnya tentu tidak semuanya berjalan dengan baik dan perlu adanya suatu hal yang dapat memberikan kenyamanan serta kepercayaan terhadap manusia lainnya, maka perlu untuk menjalin sebuah perjanjian atau perikatan sebagai jalan untuk menyatukan para pihak.

Perjanjian mengandung arti "suatu peristiwa di mana seorang berjanji kepada seoarang lain atau di mana dua orang itu saling berjanji untuk melaksanakan suatu hal."30 Adanya perjanjian bertujuan untuk mewujudkan suatu tujuan bersama dari pihak yang melakukan perjanjian supaya tidak menghasilkan kerugian bagi pihak yang terikat oleh perjanjian tersebut.

Dalam buku Perjanjian Syariah memberikan pengertian bahwa istilah "perjanjian" dalam hukum Indonesia

29 Amiur Nuruddin dan Azhari Akmal Tarigan, Hukum Perdata Islam di Indonesia Studi Kritis Perkembangan Hukum Islam dan Fikih, UU No 1/1974 sampai KHI, ( Jakarta : Kencana Prenada Media Grup 2012) cet. Ke-4, 211.

${ }^{30}$ Subekti, Hukum Perjanjian, buku hukum yang paling banyak dicari oleh pembaca, mahasiswa dan dosen, ( Jakarta : pt Intermasa, 2014), cet. Ke- 27, 1 
disebut "akad" dalam hukum Islam. Kata akad berasal dari kata al-'aqd, yang berarti mengikat, menyambung atau menghubungkan $a r-r a b t .{ }^{31}$

Pengertian lain menjelaskan secara etimologis perjanjian (yang dalam Bahasa Arab diistilahkan dengan Mu'ahadah Ittifa', akad) atau kontrak, Yan Pramadya Puspa memberikan pengertian bahwa perjanjian atau persetujuan dapat diartikan suatu perbuatan di mana seorang atau lebih mengikatkan dirinya terhadap seseorang lain atau lebih, sedangkan WJS Poerwadarminta dalam bukunya Kamus Umum Bahasa Indonesia memberikan defenisi/pengertian perjanjian tersebut yaitu persetujuan (tertulis atau dengan lisan) yang dibuat oleh dua pihak atau lebih yang mana berjanji akan menaati apa yang tersebut di persetujuan itu. ${ }^{32}$ Maka adanya perjanjian berarti pihak yang terkait telah sepenuhnya berjanji untuk mendapatkan yang disetujui oleh para pihak.

Pengertian di atas mengenai perjanjian senada dengan penjelasan di Kitab Undang-Undang Hukum Perdata pada BAB II Tentang perikatanperikatan yang dilahirkan dari kotrak atau perjanjian Bagian Kesatu Pasal 1313 memberikan penjelasan bahwa perjanjian adalah suatu perbuatan dengan mana satu orang atau lebih mengikatkan dirinya terhadap satu orang lain atau lebih. ${ }^{33}$ ini menghasilkan suatu ikatan tertentu baik dilakukan satu orang atau lebih dan tidak terikat jumlahnya sampai adanya

${ }^{31}$ Ahmad abu al-Fath, Kitab al-Mu'amalat fi asy-Syari'ah al-Iaslamiyyah wa al-Qawanin alMishriyyah, (Mesir: Matba'ah al-Busfir, 1913), I: 139 Lihat juga Asy Syaukani, Fath al-Qadir, (Mesir: Mushtafa al-Babii al-Halabi, 1964), II : 4

32 Chairuman Pasaribu dan Suharwardi, Hukum Perjanjian dalam Islam, (Jakarta: Sinar Grafika, 2004), cet.Ke-3, 1

33 Kitab Lengkap KUHPer, KUHAPer, KUHP, KUHAP, KUHD. (Gejayan Yogyakarta : Pustaka Yustisia, 2013), cet.Ke-4, 315 kesepakatan bersama tentang jumlah pihak yang mau melakukan perjanjian.

Selain itu perjanjian dalam AlQur'an juga telah Allah jelaskan dalam Surat Al-Mai'dah ayat 1 yang berbunyi sebagai berikut :

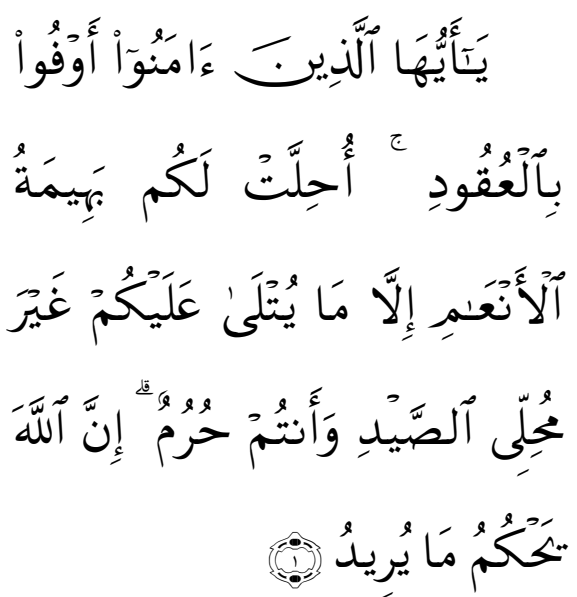

Artinya : "Hai orang-orang yang beriman, penuhilah aqad-aqad itu ${ }^{34}$ dihalalkan bagimu binatang ternak, kecuali yang akan dibacakan kepadamu. (yang demikian itu) dengan tidak menghalalkan berburu ketika kamu sedang mengerjakan haji. Sesungguhnya Allah menetapkan hukum-hukum menurut yang dikehendaki-Nya". 35

\section{Kriteria Perjanjian dalam Hukum Perdata}

Pihak yang melakukan sebuah perjanjian menginginkan perjanjian yang dilaksanakannya itu sesuai dengan ketentuan yang berlaku misalnya sesuai dengan Kitab Undang-undnag Hukum Perdata atau sejenis peraturan lainnya, yang memang para pihak sangat mempercayai kekuatan perjanjian yang dilakukannya, kriteria perjanjian sendiri Sayyid Sabiq dalam buku Hukum Perjanjian dalam Islam menjelaskan

34 Aqad (perjanjian) mencakup: janji prasetia hamba kepada Allah dan Perjanjian yang dibuat oleh manusia dalam pergaulan sesamanya.

${ }^{35}$ Kementrian Agama Republik Indonesia Al-Qur'an dan Terjemahannya, (Surabaya : Halim Publising dan Distributing, 2013), Al-Qur'an Suraat Al-Maidah (5) : 1,106 
bahwa syarat sahnya perjanjian yaitu dapat ditinjau sebagai berikut :

a. Tidak menyalahi hukum syari'at yang disepakati adanya.

b. Harus sama ridha dan ada pilihan

c. Harus jelas dan gamblang. ${ }^{36}$

Secara jelas Sayyid Sabiq menjelaskan bahwa ketiga unsur tersebut harus ada dalam suatu perjanjian berguna untuk menilai sah atau tidaknya sebuah perjanjian yang dilakukan oleh pihak yang melangsungkan perjanjian, sehingga dalam perjanjian yang dilaksanakan pihak yang melakukan perjanjian tidak merasa dirugikan satu sama lain dengan tujuan supaya terwujudnya perjanjian yang baik dan benar sesuai dengan ketentuan yang berlaku dan sesuai dengan kesepakatan para pihak.

Kriteria perjanjanjian dalam Hukum Perdata sendiri dijelaskan dalam Bagian Kedua tentang syaratsyarat yang diperlukan untuk sahnya sebuah perjanjian di Pasal 1320 menjelaskan bahwa untuk sahnya suatu perjanjian diperlukan empat syarat yaitu sebagai berikut :

1. Sepakat mereka yang mengikatkan dirinya

2. Kecakapan untuk membuat suatu perikatan

3. Suatu hal tertentu

4. Suatu sebab yang halal ${ }^{37}$

Adanya kata sepakat bagi mereka yang mengikat diri adalah adanya kemauan yang bebas sebagai syarat pertama untuk perjanjian yang sah, kemudian cakap maksudnya adalah kedua belah pihak harus cakap menurut hukum untuk bertindak sendiri, suatu hal tertentu maksudnya adalah yang diperjanjikan dalam suatu perjanjian haruslah suatu hal atau suatu barang yang cukup jelas atau tertentu, dan

36 Chairuman Pasaribu dan Suharwardi, Hukum Perjanjian dalam Islam, 3.

37 Kitab Lengkap KUHPer, KUHAPer, KUHP, KUHAP, KUHD. 317. suatu sebab atau kuasa yang halal artinya perjanjian itu tidak dilarang atau tidak bertentangan dengan peraturan perUndang-Undangan. Sehingga apa yang diperjanjikan oleh pihak yang terikat tidak bertentangan dengan peraturan yang berlaku.

Selain hal tersebut kecakapan pihak yang akan melakukan perjanjian haruslah sesuai dengan ketentaun perUndang-Undangan sehingga nanti perjanjian yang dibuat tidaklah bertentangan, namun ketentuan yang menjelaskan bahwa pihak yang tidak cakap untuk membuat suatu perjanjian adalah 1) orang-orang yang belum dewasa 2) mereka yang ditaruh di bawah pengampunan 3) orang-orang perempuan, dalam hal-hal yang ditetapkan oleh Undang-Undang, dan pada umumnya semua orang kepada siapa Undang-Undang telah melarang membuat perjanjian-perjanjian tertentu. ${ }^{38}$

Syarat-syarat sahnya perjanjian sebagaimana tersebut di atas Patrik dalam karya tulis jurnal study Islam menjelaskan bahwa syarat sahnya perjanjian dapat dapat dikategorikan menjadi dua, yaitu kategori syarat subjektif dan kategori syarat objektif. Syarat subjektif yaitu sepakat mereka yang mengaitkan diri dan syarat kecakapan untuk membuat perjanjian. Apabila syarat subjektif tidak dapat dipenuhi maka perjanjian dapat dibatalkan (Vernieitigbaar). Syarat objektif yaitu suatu syarat hal tertentu dan syarat suatu sebab yang halal. Apabila dalam perjanjian syarat objektif tidak terpenuhi, maka perjanjian adalah batal demi hukum. ${ }^{39}$

Akhirnya dari pembahasan di atas bisa memberikan pemahaman bahwa

38 Kitab Lengkap KUHPer, KUHAPer, KUHP, KUHAP, KUHD. 318.

39 Hasanudin, "Kedudukan taklik talak dalam perkawinan ditnjau dari hukum Islam dan Hukum Positif'. Medina-Te, Jurnal Study Islam, Volume, 1 (Juni 2016) : 47. 
perjanjian harus memenuhi syarat sahnya perjanjian sebagaimana sudah ditentukan dalam pasal 1320 Kitab Undang-Undang Hukum Perdata. Maka dengan dipenuhinya empat syarat sahnya perjanjian tersebut, maka suatu perjanjian manjadi sah dan mengikat secara hukum bagi para pihak yang membutnya. ${ }^{40}$ Sehingga perjanjian itu dinilai sah dan tidak melanggar peraturan yang berlaku.

\section{Hukum Perjanjian dalam Islam \\ a. Istilah dan Konsep Perikatan dalam Hukum Islam}

Dalam hukum Islam kontemporer digunakan istilah iltizam untuk menyebut perikatan (verbintenis) dan istilah akad untuk menyebut perjanjian (overeenkmost) dan bakan untuk menyebut kontrak (contract). Istilah terakhir yaitu akad, merupakan istilah tua yang sudah digunakan seja zaman klasik sehingga sudah dangat baku. Sedangkan istilah pertama, yaitu iltizam, merupakan istilah baru untuk menyebut perikatan secara umum, meskipun istilah itu sendiri juga sudah tua. Semula dalam hukum Islampra modern, istilah iltizam hanya dipakai untuk menunjukan perikatan yang timbul dari kehendak sepihak saja, hanya kadang-kadang dipakai dalam arti perikatan yang timbul dari perjanjian. $^{41}$ Baru pada zaman modern, istilah iltizam digunakan untuk menyebut perikatan secara keseluruhan.

Dengan begitu kita dapat mengatakan bahwa perikatan (iltizam) dalam hukum Islam adalah terisinya dzimmah seseorang atau suatu pihak dengan suatu hak yang wajib

${ }^{40}$ Suharnoko, Hukum Perjanjian Teori dan Analisa Kasus, (Jakarta: Fajar Interpratama Offest, 2012), cet.Ke-12, 1

41 As-Sanhuri, Mashadir al-Haqq fi alFiqhal-Islami. Dirasah muqaranahbi al-fiqh alGharibi (Ttp: Dar al-Hana li ath-Thiba'ah wa anNasyr, 1958), I: 9-10. Lihat juga Syamsul Anwar, Hukum Perjanjian Syariah, (Jakarta: Raja Grapindo Persada, 2007), 48 ditunaikannya kepada orang atau pihak lain. Pada sisi lain Mustafa az-Zarqa mendefinisikan perikatan sebagai, keadaan di mana seseorang diwajibkan menurut hukum syara untuk melakukan sesuatu atau tidak melakukan sesuatu bagi kepantingan orang lain.

\section{b. Macam-macam Perikatan dalam Hukum Islam}

Apabila dilihat dari segi objeknya, maka secara garis besar setidaknya ada empat macam perikatan yaitu :

1. Perikatan Utang (Al-Iltizam bi adDain)

Dengan perikatan utangdimaksudkan suatu bentuk perikatan yang objeknya adalah sejumlah uang atau sejumlah benda, missal (misli). ${ }^{42}$ Kunci untuk memahami konsep utang dala hukum Islam adalah bahwa utang itu dinyatakan sebagai suatu yang terletak dalam dzimmah (tanggunagan) seseorang.

2. Perikatan Benda (Al-Iltizam bi al'Ain)

Perikatan benda ini ada dalam suatu perikatan yang objeknya adalah benda tertentu yang tidak dapat diganti dengan yang lain. Dengan kata lain, perikatan benda adalah suatu perikatan untuk menyerahkan suatu benda tertentu, seperti menyerahkan kembali benda yang sudah selesaisewanya kepada pemiliknya dalam kasus sewamenyewa, atau mengembalikan barang yang dititipkan pada waktu diminta kembali oleh pemiliknya.

3. Perikatan Kerja/Melakukan sesuatu (Al-Iltizam bi al-'Amal)

42 Yang dimaksud dengan benda missal dalam hukum Islam adalah benda yang ada contohnya di pasar atau benda yang terdapat sama lainnya di pasar, seperti sepeda, mobil dan sebagainya di mana mobil merek yang sama bukan hanya satu, akan tetapi banyak lainnya yang sama. Lain halnya dengan lukisan tertentu dari pelukis tertentu, maka tulisan tersebut tidak ada duanya dan hanya itulah satu-satunya yang ada. 
Perikatan kerja melakukan sesuatu adalah suatu hubungan hukum antara dua pihak untuk melakukan sesuatu, sumber perikatan kerja di sini adalah akad istisna dan ijarah. Akad istisna adalah perjanjian untuk membuat sesuatu sedangkan akad ijarah adalah suatu akad atas beban yang objeknya adalah manfaat dan jasa.

4. Perikatan menjamin (Al-Iltizam bi at-Tautsiq)

Merupakan suatu perikatan yang objeknya adalah menanggung (menjamin) suatu perikatan. Maksudnya, pihak ketiga mengikatkan diri untuk menanggung perikatan pihak kedua terhadap pihak pertama.

Di Indonesia pembacaan taklik talak dilakukan oleh suami setelah akad nikah. Pembacaan taklik talak ini bukan suatu keharusan, tetapi hanya sekedar suka rela, tetapi pada umumnya hampir semua suami mengucapkan taklik talak setelah akad nikah. Hal ini diadakan dengan tujuan untuk melindungi kepentingan istri dari kemungkinan terjadinya kekerasan dalam rumah tangga. ${ }^{43}$

Sighat taklik talak sebenarnya tidak termasuk ke dalam perjanjian perkawinan menurut Undang-Undang nomor 1 tahun 1974, karena perjanjian yang dimaksud dalam Undang-Undang nomor 1 tahun 1974 merupakan perjanjian kedua belah pihak (suami istri) akan tetapi dalam Sighat taklik talak hanya kehendak sepihak saja yang diucapkan oleh suami setelah akad nikah. $^{44}$

Kitab Undang-Undang Hukum Perdata menjelaskan mengenai perjanjian, idealnya perjanjian itu dilakukan oleh dua belah pihak atau

${ }^{43}$ Wasman dan wardah Nuroniyah, Hukum Perkawinan Islam di Indonesia Perbandingan Fiqih dan Hukum Positif, 133

44 Henry Lee A Weng, Beberapa Segi Hukum dalam Perjanjian Perkawinan, 218 lebih dan tidak dilakukan oleh sepihak sebagaimana perjanjian Sighat taklik talak, maka dalam Kitab UndangUndang Hukum Perdata dijelaskan bahwa yang dimaksud perjanjian pasal 1313 yaitu "suatu perjanjian adalah suatu perbuatan dengan mana satu orang atau lebih mengikatkan dirinya terhadap satu orang lain atau lebih."45

Jika dilihat dari segi kekuatan Hukum maka, perjalanan ketentuan Sighat taklik talak dalam UndangUndang dan Kompilasi Hukum Islam masih bersebrangan kenyataanya dalam Undang-Undang nomor 1 tahun 1974 tidak ada pasal yang membahas mengenai taklik talak sedangakan dalam Kompilasi Hukum Islam dijelaskan, harusnya adanya suatu peraturan yang harus saling menguatkan akan tetapi dalam peraturan Sighat taklik talak ini penulis menganalisa antara Undang-Undang nomor 1 tahun 1974 dan Kompilasi Hukum Islam tidak adanya kekuatan hukum yang saling menguatkan. Seperti halnya dijelaskan dalam UndangUndang noor 1 tahun 1974 dalam pasal 29 mengenai perjanjian perkawinan tidak sedikitpun menjelasksan mengenai sigat taklik talak yang berbunyi :

1. Pada waktu atau sebelum perkawinan dilangsungkan, kedua pihak atas persetujuan bersama dapat mengadakan perjanjian tertulis yang disahkan oleh pihak ketiga yang mana sepanjang pihak ketiga tersangkut

2. Perjanjian tersebut tidak dapat disahkan bilamana melanggar batasbata hukum, agama kesusilaan

3. Perjanjian tersebut berlaku sejak perkawinan dilangsungkan

4. Selama perkawinan berlangung perjanjian tersebut tidak dapat dirubah, kecuali bila dari kedua

45 Kitab Lengkap KUHPer, KUHAPer, KUHP, KUHAP, KUHD. 316 
belah pihak ada persetujuan untuk merubah dan perubahan tidak merugikan pihak ketiga. ${ }^{46}$

Pasal tersebut tidak sedikitpun membahas mengenai ketentuan Sighat taklik talak, akan tetepi berbeda pembahasan jika kita bandingkan dengan ketentuan yang dibahas dalam pembahasan taklik talak di Kompilasi Hukum Islam pasal 45 yang berbunyi : "kedua calon mempelai dapat mengadakan perjanjian perkawinan dalam bentuk :

1. Taklik talak; dan

2. Perjanjian lain yang tidak bertentangan dengan hukum Islam.

Selanjutnya dalam pasal 46 menjabarkan mengenai ketentuanketentuan takliak talak yaitu sebagai berikut :

1. Isi taklik talak tidak boleh bertentangan dengan hukum Islam

2. Apabila keadaan yang disyaratkan dalam taklik talak betul-betul terjadi kemudian, tidak dengan sendirinya talak jatuh. Supaya talak sungguh-sungguh jatuh, istri harus megajukan persoalannya ke Pengadilan Agama

3. Perjanjian taklik talak bukan sutu perjanjian yang wajib diadakan pada setiap perkawinan, akan tetapi sekali taklik talak sudah diperjanjikan tidak dapat dicabut kembali. $^{47}$

Ayat (3) di atas sepintas bertentangan dengan pasal 29 Undangudang nomor 1 tahun 1974 ayat (4), yang mengatur bahwa selama perkawinan berlangsung perjanjian tidak dapat dirubah kecuali ada persetujuan kedua belah pihak, dan tidak merugikan pihak ketiga. Dari

${ }^{46}$ Undang-Undang R.I Nomor 1 tahun 1974 tentang Perkawinan dan Kompilasi Hukum Islam,

${ }^{47}$ Undang-Undang R.I Nomor 1 tahun 1974 tentang Perkawinan dan Kompilasi Hukum Islam, sinilah maka dalam penjelasannya disebutkan tidak termasuk taklik talak. Dan Naskah perjanjian taklik talak biasanya dilampirkan dalam salinan akta Nikah yang sudah ditanda tangani suami, oleh karena itu, perjanjian taklik talak sekali sudah diperjanjikan, tidak dapat dicabut kembali.

Kemudian jika kita perhatikan, pasal 45 Kompilasi Hukum Islam jelas bertentangan dengan pasal 29 UndangUndang nomor1 tahun 1974 dinyatakan bahwa "yang dimaksud dengan perjanjian" dalam pasal ini tidak termasuk "taklik talak", aka tetapi dalan Kompilasin Hukum Islam jelas ditegaskan bahwa perjanjian perkawinan bisa dalam bentuk taklik talak dan bisa dalam perjanjian lain yang tidak bertentangan dengan hukum Islam. $^{48}$

Hanya saja ketentuan taklik talak yang sekarang berjalan di Indonsia ini berjalan atas peraturan Menteri Aagma nomor 3 tahun 1975 pasal 11 menyebutkan bahwa :

1. Calon suami isri dapat mengadakan perjanjian sepanjang tidak bertentangan dengan hukum Islam

2. Perjanjian yang berupa taklik talak dianggap sah, apabila perjanjian itu diucapkan dan ditandatangani oleh suami setelah akad nikah dilaksanakan

3. Sighat taklik talak ditentukan Menteri Agama.

Maka, dari sinilah ketentuan Sighat taklik talak yang ada di dalam Kompilasi Hukum Islam dan yang sudah berjalan di Indonesia yang saat ini berjalan, sehingga sampai sekarang setelah akad nikah biasanya suami membacakan taklk talak dan menandatanganinya dan dibimbing oleh Petugas Pencatat Nikah.

${ }^{48}$ Wasman dan wardah Nuroniyah, Hukum Perkawinan Islam di Indonesia Perbandingan Fiqih dan Hukum Positif, 179 


\section{Kesimpulan}

Sighat taklik talak merupakan bukan hal yang tabu dikalangan masyarakat Indonesia, sehingga taklik talak dalam perkawinan yang dilakukan oleh orang Islam yang berada di Indonesia dan menjamur dikalangan masyarakat menilai bahwa taklik talak dalam perkawinan merupakan sebuah keharusan atau sebuah kewajiban, jika tidak melaksanakan taklik talak maka dinilai tidak sesuai dengan ketentaun yang berlaku. Padahal dalam pelaksanaannya jika ditinjau dari beberapa aspek, mulai dari aspek kekuatan hukum seperti dilihat dari Kitab Undang-Undang Hukum Perdata maka penulis dapat menyimpulkan sebagai berikut:

1. Jika ditinjau dari Kitab UndangUndang Hukum Perdata, ketentuan taklik talak yang sudah berlaku di Indonesia, tidak termsuk kepada perjanjian pada umumnya, karena tidak sesuai dengan pasal 1320 yang menjelaskan kriteria persyaratan dan pasal 1315 mengenai perjanjian sepihak dalam Kitab UndangUndang Hukum Perdata.

2. Dengan demikian ketentuan sighat taklik talak yang tertera dalam Kompilasi Hukum Islam, jika ditinjau dari Fiqih Tidak termasuk kepada persyaratan taklik talak sebagimana disepakati Imam Mazhab.

Maka berdasarkan analisa yang telah dilakukan, bahwa ketentuan taklik talak jika ditinjau dari Perjanjian Kitab Undang-undnag Hukum Perdata banyak yang tidak sesuainya, sehingga taklik talak tidak termasuk kedalam perjanjian yang ditentukan oleh Kitab UndangUndang Hukum Perdata.

\section{DAFTAR PUSTAKA}

Abdullah, Marhainis. Hukum Perdata Material. Jakarta: Rawamangun Kencana, 2011.

Ali, Mohamad Duad. Hukum Islam Pengantar Ilmu Hukum dan Tata Hukum Islam di Indonesia. Jakarta : Raja Grapindo Persada, 2015.

Ali, Zainuddin. Hukum Perdata Islam. Jakarta : Sinar Grafika, 2012.

Anwar, Syamsul. Hukum Perjanjian Syariah studi tentang akad dalam Fikih Muamalah. Jakarta : Raja Grafika Persada, 2010.

Ash Shiddieqy, T.M. Hasbi. Pengantar Fiqih Muamalah. Jakarta: Bulan Bintang, 1947.

Boediono, Abdul Rahman. Peradilan Agama dan Hukum Islam di Indonesia. Malang: Bayumedia Publishing. 2003.

Dewi, Gemala. Hukum Perikatan Islam di Indonesia, Jakarta : Kencana Prenanda Media Group, 2013.

Kitab Lengkap KUHPer, KUHAPer, KUHP, KUHAP, KUHD. Gejayan Yogyakarta : Pustaka Yustisia, 2013.

Kitab Undang-Undang Hukum Perdata. Bandung : Fokusindo Mandiri. 2013.

Kompilasi Hukum Islam, Bandung : Citra Umbara, 2012.

Nurudin, Amir and Azhari Akmal Tarigan. Hukum Perdata Islam di Indonesia. Jakarta : Fajar Interpratama. 2012.

Pasaribu, Chairuman and Suhrawardi K. Lubis. Hukum Perjanjian dalm Islam. Jakarta : Sinar Grafika, 2014.

Prodjohamidjodjo, Martiman Hukum Perkawinan di Indonesia. Indonesia : Legal Center Publishing, 2002.

Saifuddin, Azwar, Metode Penelitian, Yogyakarta: Pustaka Pelajar. 1998.

Saifullah, Muahammad, Muhamad Arifin and Ahmad Izzuddin. Hukum Islam Solusi Permasalahan Keluarga. Yogyakarta : Universitas Islam Indonesa press, 2005. 
Shomad, Abd, Hukum Islam. Jakarta: Kencana Prenada Media Grop, 2010.

Subekti, Hukum Perjanjian buku hukum yang paling banyak dicari oleh pembaca, mahasiswa dan dosen, Jakarta : Intermasa, 2014.

Sugiyono, Metode Penelitian Kuantitatif, Kualitatif dan R.B. Bandung, Alfabeta, 2013.

Suharnoko, Hukum Perjanjian Teori dan Praktek. Jakarta: Kencana Rawamangun, 2004.

Surakhmad, Winarno. Pengantar Penelitian Ilmiah, Dasar, Metode dan Teknik. Bandung: Penerbit Tarsito, 1998.

Syarifuddin, Amir, Hukum Perkawina di Indonesia. Jakarta : Kencan Abadi Jaya, 2011.

Thalib, sayuti, Hukum Keluarga Indonesia, Jakarta : Universitas Islam Indonesa press, 2011.

Undang-Undang Perkawinan, Bandung : Citra Umbara, 2012.

Wasman and Wardah Nurroniyah. Hukum Perkawinan Islam di Indonesia Perbandingan Hukum Fiqih dan Hukum Positif, Yogyakarta : teras, 2011.

Weng, Henry Lee A. Beberapa Segi Hukum dalam Perjanjian Perkawinan. Medan : Rainbow, 1990.

Zed, Mestika, Metode Penelitian Kepustakaan. Jakarta: Yayasan Obor Indonesia, 2004.

\section{Jurnal Ilmiah}

Hasanudin, "Kedudukan Taklik Talak Dalam Perkawinan Ditnjau Dari Hukum Islam Dan Hukum Positif'. Medina-Te, Jurnal Study Islam, Volume, 1 (Juni 2016) : 45-59.

Mutohin, "Taklik Talak Dalam Presfektif Gender". MUWAZAH, Volume. 4:2, (Desember 2012) : 264-276.

\section{Website}

Nasution, Khairudin "kekeliruan Spiritual Perempuan Dalam Taklik Talak dan Perjanjian Perkawinan”, 2008.
http://www.badilag.net/data/ARTIKEL/ Kekuatan Spiritual Perempuan.pdf. Diakses pada tanggal 23 Maret 2018 